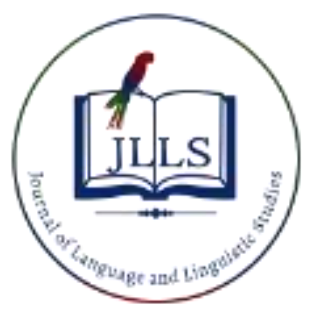

\title{
The creative use of DEFEAT IS CONTROL in metaphors for sport: A study of NBA news headlines written in Chinese
}

\author{
Kuan-Chung Huang a * ID, Ming-Yu Tseng b ID \\ ${ }^{a}$ National Sun Yat-sen University, Department of Foreign Languages and Literature, Kaohsiung 804, Taiwan \\ ${ }^{b}$ National Sun Yat-sen University, Department of Foreign Languages and Literature, Kaohsiung 804, Taiwan \\ APA Citation:
}

Huang, K.-C., \& Tseng, M.-Y. (2020). The creative use of DEFEAT IS CONTROL in metaphors for sport: A study of NBA headlines written in Chinese. Journal of Language and Linguistic Studies, 16(1), 14-29. Doi: 10.17263/jlls.712632

Submission Date:.01/01/2020

Acceptance Date: 03/12/2020

\begin{abstract}
Many studies investigated metaphors in news; however, few of them focused specifically on headlines. By investigating metaphors in 133 collected NBA news headlines written in Chinese, this paper analyzes the creativity in them. Conceptual Metaphor Theory, including conceptual metonymy, is adopted to discuss creative linguistic metaphors and their corresponding conceptual mappings based on diverse translated names of NBA teams and on specific verbs associated with them. Blending Theory is exploited to further account for the process of metaphorical creativity with the names of the teams being involved. As a whole, the findings show that the concept of defeat is creatively utilized as it is physically and/or socially constructed with the co-use of translated NBA team names and the associated verbs in Chinese. As for the process of the metaphorical creativity, three ways of achieving novelty is revealed, involving the names of the winner, the loser, or both of them respectively. Furthermore, because the data transcends the boundaries of countries, creativity is afforded and extended by reporting in Chinese a sport event taking place in an English-speaking country.
\end{abstract}

(C) 2020 JLLS and the Authors - Published by JLLS.

Keywords: Chinese; cognitive approach; creativity; news headline; sport metaphor

\section{Introduction}

News headlines serve important functions in constructing news, such as attracting the reader's attention (Molek-Kozakowska, 2013) and summarizing the full story (Silaški, 2009). One of the means of gracing news headlines is to exploit metaphors. According to Lakoff and Johnson (1980), metaphors are widely used because they are the primary characteristic of our daily language. For example, as Charteris-Black (2004) points out, the competitive nature of sport games makes it suitable for sport reports to employ war metaphors, e.g. through the conceptual metaphor FOOTBALL IS WAR. CharterisBlack (2004, p. 113) further explains that WAR is the most basic scheme of SPORTS, and accordingly words like attack and defeat are seen as common conventional metaphors in sports reports. Nevertheless, as Tseng (2006) points out, the conventionality of metaphors is in relative terms and hence a matter of

\footnotetext{
${ }^{*}$ Corresponding author. Tel.: +886-7-5252000 Ext 3151

E-mail address: mytseng@mail.nsysu.edu.tw
} 
degrees, ranging from dead, through common, to active and relatively fresh or unconventional metaphors. Conventional as the sport-as-war conceptual metaphor may appear to be, the actual linguistic expression utilizing it can be fresh. For example, in Kövecses's (2010a) study of factors that induce metaphorical creativity in the news headline of American football games, he cites fresh sport metaphor, e.g. 'Air Force torpedoes the Navy' and 'Clemson cooks Rice' (Aitchison, 1987, as cited in Kövecses, 2010a). Since these games are activities entailing two rivals and a result of winning or losing, and accordingly, the concept of DEFEAT is creatively operationalized.

In Taiwan, baseball, instead of basketball, has been thought of as its national sport, but people's interest in basketball news has increased since a global craze known as Linsanity took place. It was generated by Jeremy Shu-How Lin's remarkable performance in 2012 when he was a player with the NBA team the New York Knicks. Linsanity swept over countries all around the world. NBA news in Chinese has become a rich source of metaphors. This paper analyzes creative metaphors for NBA news headlines written in Chinese and discusses the conceptual metaphor operationalized in them and the creativity of the linguistic representations of such metaphors. Nevertheless, different from Kövecses's (2010a) research, the data of this paper transcends the boundaries of countries as the event that took place in the US is reported in traditional Chinese.

\section{Theoretical background}

\subsection{Conceptual metaphor theory: Metaphorical mappings and metonymy}

The tenet of Lakoff and Johnson's (1980) Conceptual Metaphor Theory (CMT) is that metaphor is thought involving mappings from a source domain to a target domain. With possible conceptual mappings between the two domains, we are able to interpret an abstract concept via a concrete domain, so that an understanding of the abstract concept can be reached (Lakoff \& Johnson, 1980; Kövecses, 2010b; Semino, 2010).

Some studies of metaphors have addressed sport as a source domain for target domains such as politics, business, and judicial opinions. For example, Pérez (2018) showed that sport is used as a source domain in political headlines in English and Spanish (e.g. POLITICS IS BASKETBALL and POLITICS IS FOOTBALL). Investigating political discourse in British English and in Lithuanian, Arcimavičienè (2008) also identified sport as a source domain for the target domain of politics (i.e. POLITICAL ACTIVITY IS SPORTS) and emphasized that in English data the sports metaphors entail elements such as race, gambling, and wrestling. In addition to the field of politics, Shields and Bredemeier (2011) pointed out that sport has been used as a source domain for business activities and political campaigns in English (e.g. BUSINESS IS SPORT and POLITICS IS SPORT). Cudd (2007, p. 55) also identified that sport was exploited as a source domain for capitalism due to the 'rule-governed nature' and 'competitively challenging nature of the activity' shared by both domains. It came as no surprise that words such as fair and score appeared in such metaphors. These sport metaphors exemplify people's ways of thinking, and this is also emphasized by Boyd (2014), who explains that because sport plays an important role in Americans' lives, sport is commonly used as a source domain to construct judicial opinions, e.g. knock-out from boxing, three strikes from baseball, punt from football, slam dunk from basketball, below par from golf, fold 'em from poker, and hat trick from soccer.

Metaphors that use sport as a target domain have also been analyzed. For example, as Lewandowski (2009) demonstrated, in English and Polish, a type of sport can be a source domain for another type of sport based on the established traditions of specific sports, e.g. A SOCCER MATCH IS A BOXING BOUT, A SOCCER TEAM IS A SAILING VESSEL, SOCCER COMPETITION IS A RACE, A SOCCER MATCH IS A GAME OF CHESS. Raffaelli and Katunar (2016, p. 128) also examined sport 
as a target source in sports discourse in Croatian and identified conceptual metaphors such as SPORT IS A WAR and SPORT IS FORCE. As they put it, in the case of tennis, '[m]any verbs used in these context, such as potopiti "to sink", pomesti "to sweep up", otpuhati "to blow away" refer to some kind of animate or inanimate agency (the sea, a person handling a broom and the wind, respectively) exerting force over another entity'. Bergh (2011, p. 89) analyzed live football commentaries in English and found that FOOTBALL IS WAR is exemplified in verbs such as blaze, catapult, explode and smash, which are used to emphasize the rapidity and violence of the football games. As the above review shows, sport metaphors have been widely used in different languages.

Unlike metaphor that involves mappings from a concrete domain onto an abstract concept, metonymy provides 'one entity to refer to another that is related to it' (Lakoff \& Johnson, 1980, p. 30). As Kövecses (2010a, p. 3) has observed, metonymy is operationalized in headlines featuring American football. For instance, in the headline 'Air Force torpedoes the Navy' (cited from Aitchison, 1987), Navy is conceptualized based on the metonymy NAME FOR THE INSTITUTION. Metonymy is also adopted in the current study as a conceptual tool for data interpretation where appropriate. For instance, as will be shown, the common metonymy of sports games-THE PLAYER(S) FOR THE TEAM-is at work in the chosen data.

\subsection{Blending theory}

According to Fauconnier and Turner (2002), Blending Theory (henceforth BT) enables us to obtain the subtle meaning because the use of multi-directional mappings is dynamic. Among the key concepts in BT are input spaces, a generic space and a blended space. In order for a case of conceptual integration to take place, at least two input spaces - conceptual packets that trigger potential mappings - are needed. A generic space is what the two input spaces have in common, and a blended space represents the emergent structure that is not inherent in the input spaces but is only activated and emerges in the act of blending (Fauconnier \& Turner 2002).

There could be incompatible aspects in the blended space. Grady et al. (1999) have suggested that the incompatible items from the respective input spaces could play a key role in realizing the meaning of a metaphor. One noticeable example is the often cited metaphor the surgeon is a butcher (Grady, Oakley \& Coulson 1999). Its meaning - The surgeon is incompetent - is located not in the domain of butchery or that of surgery but in the blended space of the two input spaces, i.e. the saving of lives associated with a surgeon vs. the killing of livestock pertaining to a butcher

Kövecses (2015, p. 68) applied BT to his analysis of the news headlines of football games 'Cowboys Corral Buffaloes' (cited from Atchison 1987). With the three input spaces (i.e. university, sports competition, and Wild West), the cowboys can be blended with the football team of one university, the buffaloes can be blended with the football team of another university, and at last the action of defeating can be blended with corralling. Kövecses (2010b, p. 285) suggests that BT enables us to gain 'a richer and more complete account of the creativity of human language and thought'. With a collection of 133 NBA headlines involving 30 names of different teams, the present study further extends the line of research into metaphorical creativity of sport headlines.

\subsection{Metaphorical creativity}

\subsubsection{Creativity as situated in a cline of conventionality}

Regarding the extent of metaphorical creativity, the notion of a cline of conventionality is useful, i.e., a continuum between conventional and unconventional metaphorical expressions in terms of their degrees of (un)conventionality (Goatly, 1997; Traugott, 1985; Tseng, 2006) (see Figure 1): 


$\begin{array}{llll}\text { Conventionality --oad metaphor } & \text { Inactive metaphor } & \text { Active metaphor } & \text { Fresh metaphor } \\ \text { 'a laughing stock' } & \text { 'He decided to take the } \\ \text { bull by the horns as } & \text { 'He wolfed food } & \text { 'Choose your } \\ \text { regards his drinking } & & \text { canvas. Color it with } \\ \text { problem and ban all } & & \text { flavor.' (an } \\ \text { alcohol from the house' } & \text { advertising poster } \\ & \text { for custom-made } \\ & \text { sandwiches and } \\ & \text { rolls) }\end{array}$

Figure 1. The cline of conventionality (based on Tseng, 2006, p. 34)

As Figure 1 suggests, one metaphor can be more or less creative than another. A dead metaphor is a metaphor whose literal meaning is not used any more but is replaced by the metaphorical meaning; most speakers using it are not even aware that it is a metaphor due to their lack of access to the origin or to the loss of its connection to the original imagery that gave rise to the metaphorical meaning of the term. Inactive metaphors are words or idioms whose meanings originated from metaphorical expressions but have been lexicalized. They differ from dead metaphors in that their metaphorical quality can be evoked, e.g. when one imagines the act of physically taking the bull by the horn and associates the action with the inner strength of bravery. Active metaphors are metaphors where metaphorical quality is more recognized than that of inactive metaphors while fresh metaphors whose expressions are novel and whose meanings might be relatively flexible subject to the context. In this study, creative metaphors refer to active and fresh metaphors.

\subsubsection{Five contextual factors of metaphorical creativity}

Kövecses (2010a) explored what contributed to metaphorical creativity and revealed that unconventional or novel metaphors in discourse are induced by five contextual factors: immediate linguistic context itself (i.e. co-text), knowledge about the major entities referred to in the discourse, physical setting (e.g. a place recently hit by a flood), social setting (i.e. a specific time and place), and immediate cultural context. In this paper, we particularly highlight the first factor because various names of NBA teams play a crucial role in the choice of verbs indicating winning or losing a game.

Kövecses (2010a) demonstrated how the immediate linguistic contexts in sports news headlines affect the choices of metaphorical verbs, displaying how the notion of defeat can be metaphorically expressed in diverse ways:

(a) Cougars drown Beavers

(b) Air Force torpedoes the Navy

(c) Cowboys corral Buffaloes

(d) Clemson cooks Rice

(Kövecses, 2010a, p. 3)

In these headlines, the proper nouns are the names of the involved football teams; the verbs are not randomly chosen but motivated by the consideration of the names of the teams. No matter whether the teams' names are animate or inanimate, the notion of defeat, one of the main pieces of information in reporting football games, can be conceptually interpreted as 'physically and/or socially controlling an entity' (Kövecses, 2010a, p. 4). For example, the winning teams (e.g. Air Force, Cowboys) are conceptualized as exercising control while the losing ones (e.g. Beavers, Rice) are conceived as losing 
control or being controlled, e.g. getting drowned or cooked. By examining such creative metaphors induced by the immediate context, Kövecses further suggests that there are three constraints to abide by in this kind of discourse. First, the content must be consistent with the frame of defeat, consisting of an activity in which a winning opponent defeats the other side, and this frame is usually the main issue in the discourse. Second, the metaphor defeat is physical/social control should be involved although it is realized by various linguistic expressions. Third, specific factors (e.g. the names of the teams) within the used frame (e.g. American football) should be consistent. The conceptual metaphor defeat is physical/social control will be further elaborated and developed in this study.

Building on Kövecses's research, this paper focuses on NBA news headlines written in Chinese and investigates diverse expressions regarding the notion of defeat. It examines how the conceptual metaphor defeat is physical/social control is operationalized in the headlines. However, different from Kövecses's (2010a) examples, the collected data transcends the boundaries of countries. To be specific, the examples are news headlines of NBA games held in the US but are composed in Chinese. Hence, the contexts across languages, locations, societies, and cultures associated with both English-speaking and Chinese-speaking communities should be considered.

Cultural factors can also have an impact on metaphorical conceptualization (Gibbs, 1999; Tseng, 2007). Kövecses (2005) also points out that the variation of metaphorical conceptualization lies in the personal and historical experiences. As for the current study, the selected data of NBA news headlines written in Chinese are also expected to reflect potential cultural factors.

How the crossing of languages and cultures enriches the linguistic expressions of sport metaphors is worth exploring. Two research questions are proposed:

(1) How can metaphors in Chinese news headlines concerning NBA game results be explained in terms of cognitive approaches to metaphors and metonymy?

(2) How can metaphorical creativity in such data be characterized?

\section{Method}

\subsection{Data}

This paper aims to scrutinize NBA metaphors in online news headlines composed in Chinese. This study does not require ethics committee approval. All the headlines are originally written in Chinese. They are translated into English by the first author of this study and are checked by the second author. A total number of 133 news headlines were collected from the website Epoch Times (大紀元新聞網) during the 2011-2012 season (from December 26th, 2011 to June 22nd, 2012) and the 2012-2013 season (from October 31st, 2012 to June 21st, 2013). There are two reasons why this site was chosen. Firstly, the news headlines collected in this study are all composed by speakers of Chinese, hence constituting authentic headlines in Chinese. Secondly, it is a searchable site that stores every piece of news stories, thus making it possible to retrieve past news headlines from it.

\subsection{Selection criteria}

For a headline to be selected, two criteria need to be met. First, the headline should contain a verb indicating the result of a match, i.e. meaning 'to defeat' or 'to be defeated' but not being defined as such in a dictionary. Following Shie's (2011) methodology regarding whether a figurative expression is lexicalized, this study relied on a Chinese online dictionary. The identified verbs were screened through an online dictionary called Revised Chinese Characters Dictionary). Only non-lexicalized metaphors 
were selected. In other words, if a verb (e.g. 打敗 'defeat') that delivers the result of NBA games already has the meaning of defeating in the dictionary, it would not be included. Second, the headline should also contain two entities involved in the event, as the frame of a sport game should include at least two opponents and the result of the game (Goffman, 1974). As such, a headline that delivers information concerning a player's injury or the trading of cards would be excluded.

\subsection{Procedures of data analysis}

The creative linguistic metaphors concerning the concept of defeat in NBA news headlines written in Chinese were identified, with special attention to the metaphorical verbs of defeat and the two entities involved in each headline. Next, CMT was applied to the analysis of the headlines in order to reveal both the use of metonymy and conceptual mappings between various verbs and the concept of defeat. Then, in order to further account for how the creative linguistic metaphors are derived in our cognition, we also adopt Fauconnier and Turner's (2002) BT. Finally, because the dataset transcends the boundaries of countries, some expressions reflecting general or specific cultural background will be explained.

\section{Results and Discussion}

\subsection{Toward a classification of NBA team names}

The chosen data belonged to the 2011-2012 and 2012-2013 NBA regular seasons and playoffs, and the number of the NBA teams that appeared in the collected data was 30 in total. The Chinese translations of the NBA teams' names are highly influenced by the meanings of their names in English. Table 1 presents a rough classification of the teams into three groups according to the ontological features or qualities of their names. This categorization is made for the sake of convenience and not in absolute terms.

Table 1. The names of 30 NBA teams in English and Chinese during 2011-2012 and 2012-2013 seasons based on Epoch Times

\begin{tabular}{|c|c|c|c|c|c|}
\hline \multicolumn{2}{|l|}{ 1. Animate } & \multicolumn{3}{|c|}{ 2. Non-Animate } & \multirow{2}{*}{$\begin{array}{l}\begin{array}{l}\text { 3.Natural } \\
\text { phenomena }\end{array} \\
\end{array}$} \\
\hline People & Animals/Insects & Arts & Materials & Transit & \\
\hline $\begin{array}{l}\text { Celtics (綠衫軍), } \\
\text { Knicks (尼克斯), } \\
\text { Sixers (76 人), } \\
\text { Wizards, (巫師/ 奇才), } \\
\text { Cavaliers (騎士), } \\
\text { Pacers (溜馬/ 步行者), } \\
\text { Warriors (勇士) Lakers } \\
\text { (湖人), Blazers ((拓荒 } \\
\text { 者/ 開拓者), Kings (國 } \\
\text { 王) }\end{array}$ & $\begin{array}{l}\text { Hawks (老鷹), } \\
\text { Hornets (黃蜂), } \\
\text { Bulls (公牛), Bucks } \\
\text { (公鹿), Raptors (暴 } \\
\text { 龍), Mavericks (小 } \\
\text { 牛), Timberwolves } \\
\text { (灰狼/ 森林狼), } \\
\text { Grizzlies (灰熊), } \\
\text { Bobcats (山貓) }\end{array}$ & $\begin{array}{l}\text { Magic (魔術 } \\
\text { ), Jazz (爵士 } \\
\text { ) }\end{array}$ & $\begin{array}{l}\text { Nets (籃網 } \\
\text { ),Pistons } \\
\text { (活塞), } \\
\text { Nuggets (金 } \\
\text { 塊), Spurs ( } \\
\text { 馬刺) }\end{array}$ & $\begin{array}{l}\text { Rockets ( } \\
\text { 火箭), } \\
\text { Clippers ( } \\
\text { 快艇/快船 } \\
\text { ) }\end{array}$ & $\begin{array}{l}\text { Heats (熱火), } \\
\text { Suns (太陽/日 } \\
\text { ), Thunder (雷 } \\
\text { 霆) }\end{array}$ \\
\hline
\end{tabular}




\subsection{Creative linguistic metaphor}

Some selected news headlines dealing with the issue of defeat are analyzed here based on the immediate linguistic context itself. In order to attract potential readers, the authors of news headlines tend to report NBA games in creative ways, exemplifying various manifestations and elaborations of the conceptual metaphor defeat is physical/social control (cf. section 2.3.2). As will be demonstrated, a wide range of verbs meaning defeat are afforded by the names of NBA teams. We tentatively distinguish physical control from social control. The former refers to controls enacted by physical strengths, weapons or tools (e.g. hunting, tearing, stinging) while the latter is more associated with control through social power or activity (e.g. deciphering, tricking someone). The distinction may not be clear-cut as the expressions of certain actions may be ambiguous. For example, tui fan (推翻) in Chinese can literally mean 'to topple (a ship)' or 'to overthrow (a dynasty)', thus covering the meanings of both physical and social control.

Table 2 is based on the conceptual metaphor defeat is physical control. As is suggested, defeat is metaphorically conceptualized as various physical actions, including stinging, burning, hunting and covering.

Table 2. Defeating associated with physical actions

\begin{tabular}{|c|c|}
\hline $\begin{array}{c}\text { Creative } \\
\text { Conceptualization }\end{array}$ & Example \\
\hline $\begin{array}{l}\text { defeating as stinging } \\
\text { someone away }\end{array}$ & $\begin{array}{l}\text { (1) 羅培茲手感湯 黃蜂蟄走公鹿 } \\
\text { With Lopez feeling fired up, Hornets stung Bucks away. }{ }^{\dagger} \text { (December } 4^{\text {th }} \text {, } \\
\text { 2012) }\end{array}$ \\
\hline $\begin{array}{l}\text { defeating as burning with } \\
\text { fire }\end{array}$ & $\begin{array}{l}\text { (2) 詹姆斯無視膝傷 熱火焚狼 } 15 \text { 連勝 } \\
\text { James ignored his knee injury; Heats burned Timberwolves with fire for } \\
\text { their } 15 \text { consecutive wins. }{ }^{\ddagger} \text { (March 5th, 2013) }\end{array}$ \\
\hline $\begin{array}{l}\text { defeating as butting } \\
\text { someone out }\end{array}$ & $\begin{array}{l}\text { (3) 羅斯傷癒復出 公牛頂走老鷹 } \\
\text { With Rose's return from injury, Bulls butted Hawks out. }{ }^{\S} \text { (February } 21^{\text {st }} \text {, } \\
\text { 2012) }\end{array}$ \\
\hline defeating as tearing & $\begin{array}{l}\text { (4) 尼克扯破籃網 穩坐東區第 } 7 \\
\text { Knicks tore Nets, occupying the } 7^{\text {th }} \text { spot in the east. (April 19 } 9^{\text {th }}, 2012 \text { ) }\end{array}$ \\
\hline defeating as hunting & $\begin{array}{l}\text { (5) 羅斯缺陣 公牛殘陣獵貓三連勝 } \\
\text { Without Rose, the rest of the players of Bulls hunted Bobcats for their } 3 \\
\text { straight wins. (January } 22^{\text {nd }}, 2012 \text { ) }\end{array}$ \\
\hline defeating as covering & $\begin{array}{l}\text { (6) 延長賽火力旺 籃網罩尼克 } \\
\text { With many points made in overtime, Nets covered Knicks. (November } 27^{\text {th }} \text {, } \\
\text { 2012) }\end{array}$ \\
\hline
\end{tabular}

Take (1) for instance. It illustrates defeating as stinging someone away, caused by specific insects with the stinger (e.g. bees, mosquitos). The metaphorical verb zhe zou (䖯走 'sting someone away') is

\footnotetext{
†Shou gan tang (手感盪 'fired up’) is a common way in Chinese to describe a player who is raring to go, very skilled, and eager to score. Lopez was one of the players of New Orleans Hornets in the 20122013 season.

James was one of the players of Miami Heats in the 2012-2013 season.

$\S$ Rose, one of the players of Chicago Bulls in the 2011-2012 season, was injured before the game.
} 
particularly chosen by the conceptualizer since the controller huang feng (黃蜂 'Hornets') belongs to a kind of insects with stings and can conduct the physical action of attacking. Moreover, the entity to be controlled gong lu (公鹿 'Bucks') happens to be among the possible animals to be stung. If the sentence were changed to gong lu zhe zou huang feng (公鹿䖯走黃蜂 'Bucks stung Hornets away'), the expression would look odd as Bucks do not have the stings to perform the action.

Cited in Table 3 are Examples (7)-(9), based on the conceptual metaphor defeat is social control.

Table 3. Defeating associated with social actions

\begin{tabular}{|c|c|}
\hline $\begin{array}{l}\text { Creative } \\
\text { conceptualization }\end{array}$ & Example \\
\hline defeating as deciphering & 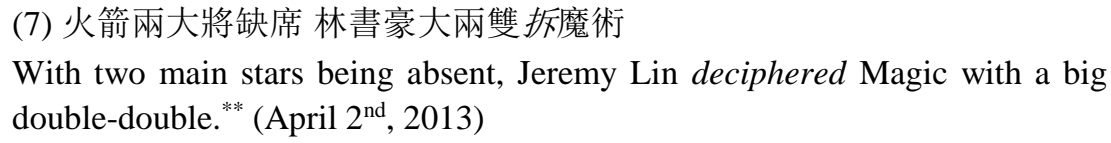 \\
\hline $\begin{array}{l}\text { defeating as } \\
\text { commanding someone to } \\
\text { do something }\end{array}$ & $\begin{array}{l}\text { (8) 林書豪連兩場兩雙 無私火箭令國王屈膝 } \\
\text { With Jeremy Lin's back-to back double-doubles, unselfish Rockets commanded } \\
\left.\text { Kings to kneel down. (April } 4^{\text {th }}, 2013\right)\end{array}$ \\
\hline $\begin{array}{l}\text { defeating as tricking } \\
\text { someone }\end{array}$ & $\begin{array}{l}\text { (9) 魔獸發威 魔術戲要山貓 } \\
\text { Howard was on fire; Magic tricked Bobcats. }{ }^{\dagger \dagger}\left(\text { January } 18^{\text {th }}, 2012\right)\end{array}$ \\
\hline
\end{tabular}

Example (7) shows that defeating is compared to the action of deciphering. Although the metaphorical verb chai (拆) may either refer to chai chuan (拆穿 'decipher something', e.g. a plot) or chai chu (拆除 'demolish something', e.g. a construction), it is interpreted as meaning the former as the entity to be controlled in (7) is mo shu (魔術 'Magic'), which is somewhat abstract.+ Regarding the controller (Jeremy Lin) as a person performing the social action, we can identify the metonymy the player(s) for the team at work (cf. footnote no. 8).

As has been shown, different names of NBA teams and specific verbs associated with them assist in composing the diverse headlines realizing the conceptual metaphor defeat is physical/social control. The NBA game is compared to exercising physical and social control; the winner is compared to the controller; the loser is conceptualized as an entity to be controlled; the notion of defeating corresponds to the action being performed. The conceptual mappings for the conceptual metaphor are demonstrated in Table 4.

\footnotetext{
** Jeremy Lin was a player of Houston Rockets in the 2012-2013 season. A double-double: a player reaches double figures in two of the five categories (i.e. points, rebounds, assists, steals, and blocks) in a game.

† Howard, who is known as mo shou (魔獸'Magic Beast') in Taiwanese media coverage, played for Orlando Magic in the 2011-2012 season.

林 The examples are respectively retrieved from http://dict.revised.moe.edu.tw/cgi-bin/cbdic/ gsweb.cgi?ccd=o07JCQ \&o=e0\&sec=sec1\&op=v\&view=2-1 and http://dict.revised.moe.edu.tw/cgibin/cbdic/gsweb.cgi. Accessed on 28th November 2018.
} 
Table 4. Conceptual mappings of defeat is physical/social control

\begin{tabular}{|l|l|l|}
\hline Source: physical/social control & & Target: defeat \\
\hline exercising physical and social control & $\longrightarrow$ & the NBA game \\
\hline the controller & $\longrightarrow$ & the winner \\
\hline the entity to be controlled & $\longrightarrow$ & the loser \\
\hline the action being performed & $\longrightarrow$ & the notion of defeating \\
\hline
\end{tabular}

In short, the analyses have shown that a multiplicity of DEFEAT verbs are used due to a rich diversity of team or player names.

\subsection{Blending between defeating and diverse inputs}

The creative linguistic metaphors are expressed based on particular metaphorical verbs. Moreover, the importance of the diverse names of NBA teams has been highlighted. Nevertheless, there seems to be different levels of metaphorical creativity to be further explored. The writers of the NBA news headlines could involve names of winners, losers, or both of these to achieve the creativity. That is, the specific verbs would not work without involving at least one NBA team name, and the process of such subtle novelty is not fully captured using CMT alone because how the levels of metaphorical creativity are developed in our minds requires further explanations. In Section 3.2, we have explained that a selected headline should include at least two opponents according to the second criterion, and this paper believes that there exist different levels on which metaphorical creativity is realized whether the metaphorical conceptualization involves the name of the winner, the loser, or both of them.

Example (10) shows an association between the notion of defeat and the metaphorical verb ji chuan (擊穿 'puncture'). However, the reason why the metaphorical creativity can be appreciated effortlessly is that in people's ways of thinking, the knowledge of the physical action of puncturing is conducted using something sharp, including animal horns, and such knowledge serves as the base for the conceptualization of defeating in this example. In terms of BT, the vital relations are explained through the integration model (see Figure 2). BT enables us to discuss the notion of defeating in relation to the concept of puncturing based on four elements: activity, controller-participant, controlled or affected participant, and purpose. These elements are the common aspects shared by both input spaces and are indicated in the generic space; they are derived from the four elements mapped from the two input spaces respectively. Input I deals with the idea of defeating, which contains an NBA game, a winner, a loser, and to defeat. Input II addresses the concept of puncturing, including a physical control, Bulls, Magic, and to puncture. In the blend, Bulls puncturing a loser in the NBA game is depicted.

(10) 帶傷羅斯準大三元 公牛擊穿魔術

With injured Rose nearly recording a triple-double, Bulls punctured Magic..$^{\S \S}$ (January $7^{\text {th }}, 2012$ )

\footnotetext{
$\$ \S$ Rose was one of the players of Chicago Bulls in the 2011-2012 season. A triple-double: a player reaches double figures in three of the five categories (i.e. points, rebounds, assists, steals, and blocks) in a game.
} 


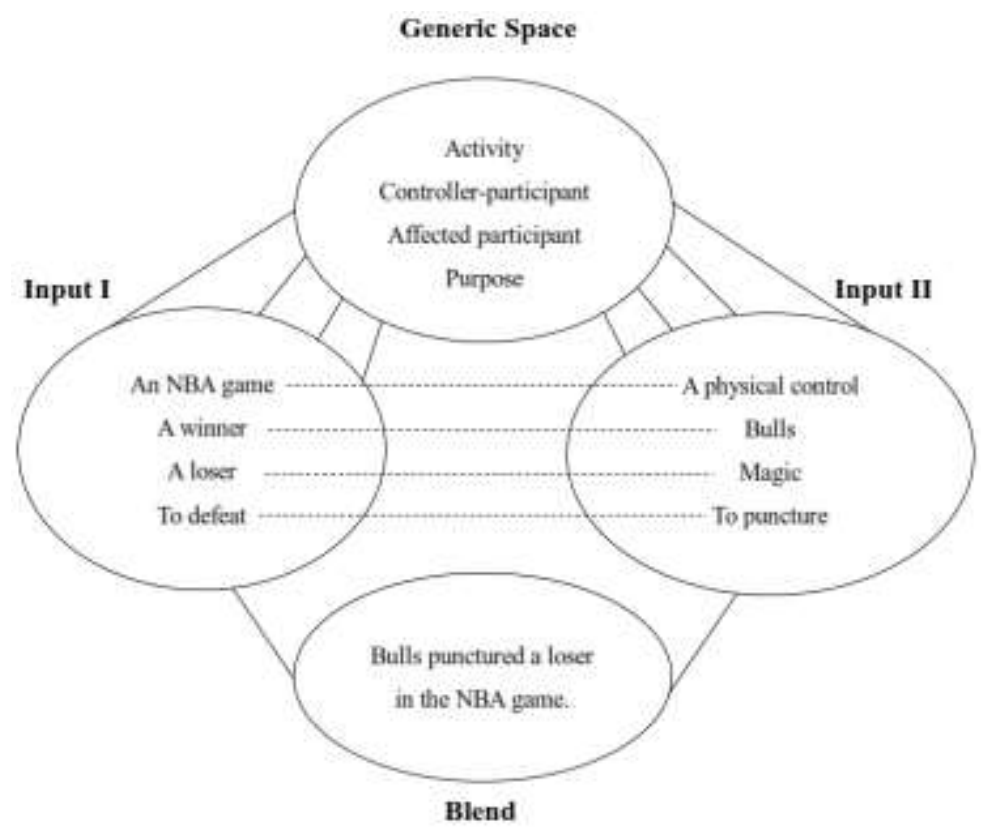

Figure 2. Conceptual Integration between defeating and puncturing

This news headline is engaging to the addressees because the name of the winner gong niu (公牛 'Bulls') perfectly matches the verb ji chuan (擊穿 'puncture'). More specifically, the team gong niu ( 公牛 'Bulls') evokes the horns feature associated with the animal and with the verb, and a similar association would not be made possible by an incompatible team name such as lan wang (籃網 'Nets'). On the other hand, the name of the loser mo shu (魔術 'Magic') does not motivate the choice of the verb in this case. In other words, the name of the winner remains in our mental space because it makes the action possible, and the name of the loser is not involved in the choice of the verb. When reading this news headline, what makes a potential reader interested in it lies in the subtle relation between Bulls and puncturing. Although it is highly unlikely to see a bull puncturing magic in the wilderness, the counterfactual presence of Bulls puncturing a loser in the NBA game can be imaginatively created. In short, although the action of puncturing is a metaphor for defeating, the creativity is achieved not by a random choice of the metaphorical verb but by the consideration of the winner's name 'Bulls'.

In some of the selected news headlines, specific names of the losers are found to well match particular verbs, so that the subtle meaning is constructed in people' minds. Take (11) for example.

\section{(11) 艾法羅、瑞迪克合力貢獻 51 分魔術撞翻快艇}

Afflalo and Redick co-achieving 51 points, Magic knocked over Clippers.*** (January 13th, 2013)

In Example (11), the name of the loser kuai ting (快艇 'Clippers') provides the background knowledge for conceptualizing the idea of DEFEAT. While some verbs are used due to the names of the winners, in Example (11) the verb zhuang fan (撞翻 'knock over') is motivated because of the name of the loser. With the illustration of Figure 3, the important relations are revealed through blending. Four key elements are highlighted in the mappings across and between input spaces and generic space. Input I represents the concept of defeating, consisting of an NBA game, a winner, a loser, and the action of

\footnotetext{
**** Afflalo and Redick were players of Orlando Magic in the 2012-2013 season.
} 
defeating itself. Input II expresses the concept of knocking over, an action involving a physical control, Magic, Clippers. A winner who knocked over Clippers in the NBA game is thus created in the blend.

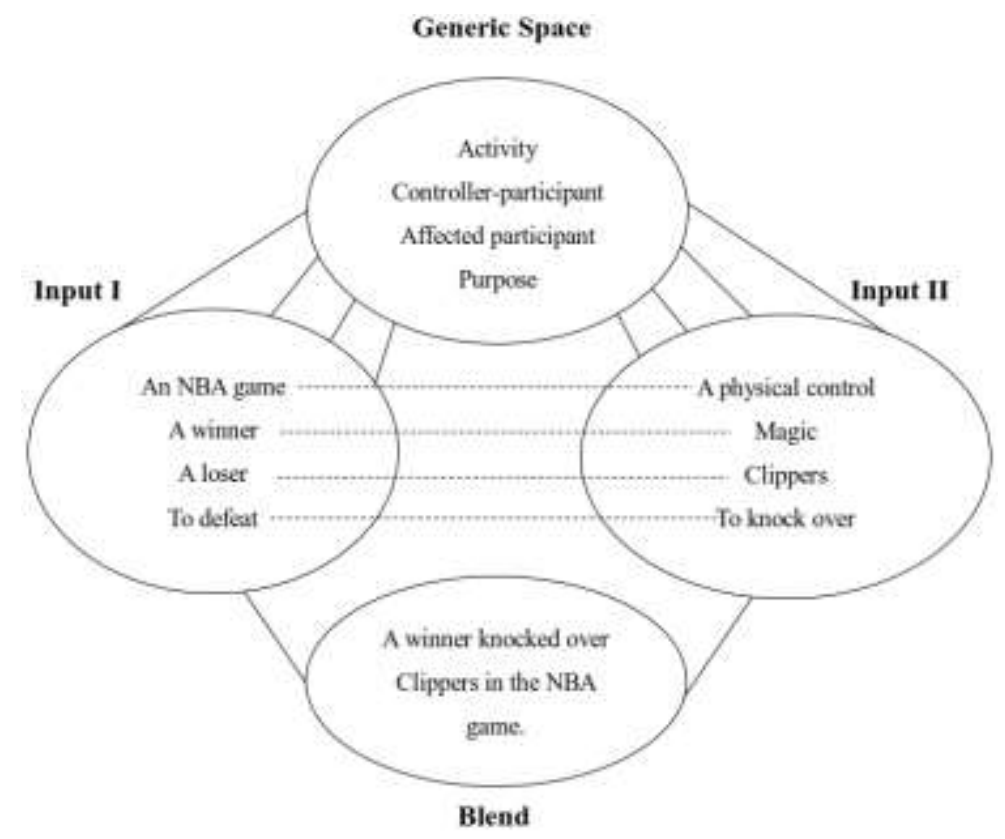

Figure 3. Conceptual Integration between defeating and knocking over

In order to further interpret the creativity, we have to recognize what aspects are emphasized when these two concepts are blended in our minds. The creativity of the news headline is appropriate because the name of the loser kuai ting (快艇 'Clippers') well matches the verb zhuang fan (撞翻 'knock over'). Namely, kuai ting (快艇 'Clippers') is capable of undergoing the action of knocking over. In contrast, the name of the winner mo shu (魔術 'Magic') is not stressed in the choice of the metaphorical action because it fails to match the action in our conception of magic. Namely, the name of the loser remains in our cognition as it activates the action, and the name of the winner is not highlighted. In the reading of this news headline, what interests the readers is the novelty by connecting the action of knocking over and the name of the loser kuai ting (快艇 'Clippers'). Even though magic is not normally perceived as capable of knocking over clippers in the real world, in the blend the counterfactual appearance of a winner knocking over Clippers in the NBA game can be subtly created.

The difference between involving the name of the winner and that of a loser mainly affects which aspect is highlighted when the writer of the NBA news headlines develops creativity. When the name of the winner is involved, the writer generates creativity by focusing on his ability to perform an action. By contrast, when the name of the loser is involved, the writer produces creativity based on the consequence of undergoing an action. Therefore, the elaboration of creative conceptualization can be finely revealed in the blend, where elements are selectively projected based on whether the ability to defeat an opponent or the consequence of being defeated is more salient. In other words, writers of NBA news headlines could focus more on the triumph of the winner or the disaster of the loser. At last, among a total of 133 selected news headlines, each of which consists at least two opponents and a result of an NBA game, only 6 headlines are identified as involving only the names of winners, which in a way stresses the victory of the winner of an NBA game, 45 headlines are identified as involving only the names of losers, and up to 82 headlines are identified as involving the names of both winners and losers to achieve subtle meaning. Due to space limitations, we will not further discuss the third situation in detail but refer the reader to Example (7), which demonstrates the involvement of the names of both the 
winner and the loser. The action of deciphering apparently requires a human agent (Jeremy Lin) and a complicated phenomenon (Magic) to be tackled.

（7）火箭兩大將缺席 林書豪大兩雙 拆魔術

With two main stars being absent, Jeremy Lin deciphered Magic with a big double-double. (April $\left.2^{\text {nd }}, 2013\right)$

\subsection{Metaphorical expressions reflecting cultural background knowledge}

While the NBA games are held in America, the selected NBA news headlines are written in Chinese. Such headlines may contain metaphorical expressions that reflect some cultural background knowledge beyond the boundaries of countries. These expressions are creatively conceptualized whether based on specific culture or general culture. Namely, the reader may need to be well aware of some cultural background knowledge to understand these expressions. Example (12) in Table 5 is presented to discuss the expression based on culture-specific information, i.e. she ri (射日 'shooting Suns').

Table 5. A culture-specific example

\begin{tabular}{|l|l|l|}
\hline $\begin{array}{l}\text { Culture-Specific } \\
\text { Expression }\end{array}$ & Specific Culture & Example \\
\hline $\begin{array}{l}\text { she ri (射日 } \\
\text { 'shooting Suns') }\end{array}$ & Chinese myth & $\begin{array}{l}\text { (12) } 48 \text { 分射日科比再創賽季新高 } \\
\text { Kobe shot Suns with a season-high } 48 \text { points. } \\
\left(\text { January } 11^{\text {th }}, 2012\right)\end{array}$ \\
\hline
\end{tabular}

In Example (12), the creative linguistic metaphor conceptualizes defeating as shooting, which is also developed from the conceptual metaphor DEFEAT IS PHYSICAL CONTROL. In addition, the metonymy THE PLAYER(S) FOR THE TEAM is used (cf. footnote no. 16). Moreover, behind this metaphorical expression is the Chinese myth regarding Hou Yi (后翠). nine suns out of ten to save people and animals. It has been passed on for centuries, so that the familiarity of the Chinese expression 射日 (she ri) enables readers of Chinese to recall the Chinese myth when attempting to understand the headline. That is, despite different creative linguistic metaphors for conceptualizing the notion of DEFEAT, when the action of shooting is used to report Suns being defeated, readers of Chinese tend to effortlessly retrieve the background knowledge of the Chinese myth to 'process them in the most productive way' (Sperber \& Wilson 2008, p. 89), and this is how the cultural expression is made relevant to the report NBA games.

Cited in Table 6 is an example related to general culture, i.e. qing ye dan (慶耶誕 'celebrating Christmas').

\footnotetext{
tit Kobe was a player of Los Angeles Lakers in the 2011-2012 season.

Ht Retrieved from https://www.britannica.com/topic/Hou-Yi. Accessed on 4th December 2018.
} 
Table 6. An example based on general culture

\begin{tabular}{|c|c|c|}
\hline $\begin{array}{l}\text { Culture-General } \\
\text { Expression }\end{array}$ & General Culture & Example \\
\hline $\begin{array}{l}\text { qing ye dan (慶耶 } \\
\text { 誕 'celebrating } \\
\text { Christmas') }\end{array}$ & Christmas & $\begin{array}{l}\text { (13) 林書豪兩雙 火箭 } 120 \text { 分烤公牛慶耶誕 } \\
\text { With Jeremy Lin recording a double-double, Rockets } \\
\text { roast Bulls to celebrate Christmas. (December } 26^{\text {th }} \text {, } \\
\text { 2012) }\end{array}$ \\
\hline
\end{tabular}

In Example (13), the creative linguistic metaphor builds on defeating as roasting, which is also based on the conceptual metaphor DEFEAT IS PHYSICAL CONTROL. Here, the headline writer connects the happening of the NBA game to the celebration of Christmas. The headline was written on December $26^{\text {th }}$, and although Taiwanese readers just spent Christmas, the time of US is one day behind than that of Taiwan, i.e. the Christmas day. By activating relevant knowledge, including the awareness of time difference between the US and Taiwan, the experience of the celebration of Christmas (e.g. eating roast meat), the reader can creatively make the widely known general cultural information relevant to the NBA reporting. The metaphorical expression based on the general culture transcends the boundaries of countries.

\section{Conclusions}

This paper reveals that creative metaphors are used in the NBA news headlines written in Chinese. In response to the first research question, this study demonstrates that when the writers construct the concept of defeat, various creative linguistic metaphors are composed based on the conceptual metaphor DEFEAT IS PHYSICAL/SOCIAL CONTROL. Whether defeat is physically or socially constructed is greatly affected by the property of the translated names of NBA teams associated with the particular verbs (e.g. Heats burned Timberwolves with fire 熱火焚狼 in (2); Knicks tore Nets 尼克扯破籃網 in (4)). Regarding the second question, which concerns how metaphorical creativity can be characterized, this study suggests three possible ways of interpreting the metaphorical creativity in NBA news headlines, i.e. involving the names of the winner, the loser, or both. Furthermore, cultural knowledge plays a role in constructing metaphorical creativity, whether it be culture-specific (e.g. shot Suns 射日 in (12)) or general (e.g. roast Bulls to celebrate Christmas 烤公牛慶耶誕 in (13)).

The current research has demonstrated how NBA news headlines are composed in Chinese by using metaphors and metonymies in order to induce clicks from potential readers. Reinforcing the key role that metaphor and metonymy jointly play in the creative process (see Hidalgo-Downing, 2016), this study contributes to research into metaphorical creativity (cf. Brône \& Feyaerts, 2006; HidalgoDowning, 2016; Langlotz, 2016; Lundmark, 2005; Semino, 2008). Because the examples transcend the boundaries of countries, the cross-cultural nature creates new possibilities for metaphorical creativity. Metaphorical creativity in the cited examples is appropriate because the intended reader is familiar with the language and culture and therefore accepts the creative metaphors as they incorporate familiar cultural elements into the reports of the NBA game. Metaphorical creativity in the headlines builds on our familiarity with the world and on our attempt to make the world slightly unfamiliar yet rich in meaning-making. More research into metaphorical creativity in cross-cultural contexts is needed in order to provide further depth, richness and insights to the findings of this study. 


\section{Ethics Committee Approval}

The authors confirm that this study does not need ethics committee approval according to the research integrity rules in authors' country.

\section{References}

Aitchen, J. (1987). Words in the mind. Oxford: Blackwell.

Arcimavičienè, L. (2008). Morality through metaphor: A cross-linguistic analysis of political discouerse. Kalbotyra 59, 11-19.

Bergh, G. (2011). Football is war: A case study of minute-by-minute football commentary. Revista

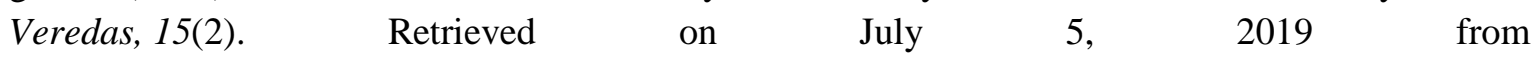
https://periodicos.ufjf.br/index.php/veredas/article/view/25079

Boyd, M. E. (2014). Riding the bench - A look at sports metaphors in judicial opinions. Harvard Journal of Sports \& Entertainment Law, 5, 245-264.

Brône, G., Feyaerts, K., \& Veale, T. (2006). Introduction: Cognitive linguistic approaches to humor. Humor: International Journal of Humor Research, 19(3), 203-228. https://doi.org/10.1515/HUMOR.2006.012

Charteris-Black, J. (2004). Corpus approaches to critical metaphor analysis. New York, NY: Palgrave Macmillan.

Cudd, A. E. (2007). Sporting metaphors: Competition and the ethos of capitalism. Journal of the Philosophy of Sport, 34, 52-67.

Fauconnier, G., \& Turner, M. (2002). The way we think: Conceptual blending and the mind's hidden complexities. New York, NY: Basic Books.

Gibbs, R. W. (1999). Taking metaphors out of our heads and putting it into the cultural world. In R. W. Gibbs \& G. Steen (Eds.), Metaphor in cognitive linguistics (pp. 145-166). Amsterdam: John Benjamins.

Goatly, A. (1997). The language of metaphors. London and New York: Routledge.

Goffman, E. (1974). Frame analysis: An essay on the organization of experience. Cambridge, MA: Harvard University Press.

Grady, J. E., Oakley, T., \& Coulson, S. (1999). Blending and metaphor. In R. W. Gibbs \& G. Steen (Eds.), Metaphor in cognitive linguistics (pp. 101-124). Amsterdam: John Benjamins.

Hidalgo-Downing, L. (2016). Metaphor and metonymy. In Rodney H. Jones (Ed.), The Routledge handbook of language and creativity (pp. 107-128). London and New York: Routledge.

Kövecses, Z. (2005). Metaphor in culture: Universality and variation. New York, NY: Oxford University Press.

Kövecses, Z. (2010a). Metaphor, Creativity, and Discourse. DELTA: Documentação e Estudos em Linguística Teórica e Aplicada,26(3). Retrieved on October 1, 2019 from http://www.scielo.br/scielo.php?script=sci_arttext\&pid=S0102-44502010000300016

Kövecses, Z. (2010b). Metaphor: A practical introduction. Oxford: Oxford University Press. 
Kövecses, Z. (2015). Where metaphors come from: Reconsidering context in metaphor. Oxford and New York: Oxford University Press.

Lakoff, G., Johnson, M. (1980). Metaphors we live by. Chicago: University of Chicago Press.

Langlotz, A. (2016). Language, creativity, and cognition. In R. H. Jones (Ed.), The Routledge handbook of language and creativity (pp. 40-60). London and New York: Routledge.

Lewandowski, M. (2009). Metaphors from other sports in the language of soccer - evidence from English and Polish. In P. Nowak \& P. Nowakowski (Eds.), Język, Komunikacja, Informacja (Language, Communication, Information) (pp. 29-48). Poznań: Sorus.

Lundmark, C. (2005). Metaphor and creativity in British magazine advertising. Unpublished PhD Dissertation, Luleå Tekniska Universitet, Luleå. Retrieved on April 28, 2019 from https://pdfs.semanticscholar.org/c744/d0a43b3b4abe5b4a1fda102f95f3325f9dd4.pdf?_ga=2.15967 5188.861762303.1571318576-1294420950.1514120294

Molek-Kozakowska, K. (2013). Towards a pragma-linguistic framework for the study of sensationalism in news headlines. Discourse \& Communication, 7, 173-197.

Raffaelli, I., \& Katunar, D. (2016). A discourse approach to conceptual metaphors: A corpus-based analysis of sports discourse in Croatian. Studia Linguistica Universitatis Iagellonicae Cracoviensis, 133, 125-147.

Revised Chinese Characters Dictionary (2018). Retrieved on May 5, 2018 from: http://dict.revised.moe.edu.tw/cbdic/search.htm).

Semino, E. (2008). Metaphor in discourse. Cambridge: Cambridge University Press.

Semino, E. (2010). Unrealistic scenarios, metaphorical blends and rhetorical strategies across genres. English Text Construction, 3, 250-274.

Shie, J.-S. (2011). Metaphors and metonymies in New York Times and Times Supplement news headlines. Journal of Pragmatics, 43, 1318-1334. https://doi.org/10.1016/j.pragma.2010.10.026

Shields, D., \& Bredemeier, B. (2011). Contest, competition, and metaphor. Journal of the Philosophy of Sport. 38.27-38.

Silaški, N. (2009). Topic-triggered metaphors in newspaper headline. Professional Communication and Translation Studies, 2, 59-66.

Sperber, D., \& Wilson, D. (2008). A deflationary account of metaphors. In R. W. Gibbs (Ed.), The Cambridge Handbook of Metaphor and Thought (pp. 84-105). Cambridge: Cambridge University Press.

Traugott, E. C. (1985). 'Conventional' and 'dead' metaphors revisited. In W. Paprotté \& R. Dirven (Eds), The ubiquity of metaphor: Metaphor in language and thought (pp. 17-57). Amsterdam: John Bejamins.

Tseng, M.-Y. (2006). Iconicity in the interplay of the literal and metaphorical. Journal of Literary Semantics, 35, 31-57.

Tseng, M._Y. (2007). Space metaphor as a signifying force in Chan poems. American Journal of Semiotics, 23, 221-241. 


\section{Spor için metaforlarda yenilginin yaratıcı kullanımı: Çince yazılan NBA haber başlıklarının incelenmesi}

\section{$\ddot{O} \mathbf{z}$}

Birçok çalışma haberlerdeki metaforları araştırmış; ancak, yalnızca bunlardan birkaçı özellikle manşetlere odaklanmıştır. Bu makale, Çince yazılmış 133 NBA haber başlığından toplanan metaforları araştırarak, içlerindeki yaratıcılığı analiz etmek için yazılmıştır. Kavramsal Metafor Teorisi, kavramsal ad aktarması da dahil olmak üzere, yaratıcı dilbilimsel metaforları ve bunların NBA ekiplerinin farklı tercüme edilmiş isimlerine ve onlarla ilişkili belirli fiillere dayanan ilgili kavramsal eşleşmeleri tartışmak için benimsenmiştir. Karıştırma Teorisi, ilgili ekiplerin isimleriyle mecazi yaratıcılık sürecini daha fazla açıklamak için kullanılmıştır. Metaforik yaratıcılık sürecine gelince, kazanan, kaybeden veya her ikisinin isimlerini içeren yenilik elde etmenin üç yolu ortaya çıkar. Ayrıca, veriler ülkelerin sınırlarını aştığı için, İngilizce konuşulan bir ülkede gerçekleşen bir spor etkinliği Çince raporlanarak yaratıcılık sağlanır ve genişletilir.

Anahtar sözcükler: Çince; bilişsel yaklaşım; yaratıcılık; haber başlığı; spor metaforu

\section{AUTHOR BIODATA}

Kuan-Chung Huang holds an MA in Linguistics from National Sun Yat-sen University, Taiwan.

Ming-Yu Tseng is Professor at National Sun Yat-sen University, Taiwan. His publications have appeared in Pragmatics \& Society, and Text \& Talk, and Journal of English for Academic Purposes. Among his most recent publications are "Where cultural references and lexical cohesion meet: Toward a multi-layer framing analysis", Pragmatics (2018) and (co-authored with Grace Zhang) "Pragmeme, adaptability, and elasticity in online medical consultations", Journal of Pragmatics (2018). 